\author{
Balogh, Péter PhD
}

baloghp@socio.u-szeged.hu

senior lecturer (University of Szeged, Department of Sociology)

\title{
Hungary in the Rural Development Cooperation Network of the European Union
}

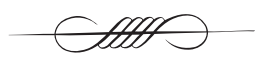

\section{Abstract}

The aim of this paper is to investigate the role and position of Hungary in the transnational cooperation projects of the rural development policy in the European Union between 2007 and 2013. On the one hand, we study - on a basis of official data - the main characteristics of the distribution of rural development projects among the EU member states by applying basic descriptive methods supplemented with certain concentration measures to quantify the inequalities of the projects and the funds this way exploring the role of Hungary in the process of project generation and fund absorption. On the other hand, we apply basic network analysis techniques and network measures to illustrate and describe the transnational cooperation network among countries in the European Union and the position of Hungary in this cooperation network. According to the results the distribution of both the projects and the financial resources allocated through these projects prove to be rather concentrated, and Hungary seems to have a kind of comparative advantage in the possibilities of the initiation of transnational cooperation projects.

KEYWORDS rural development, cooperation, social embeddedness, network analysis

DOI 10.14232/belv.2016.1.8 http://dx.doi.org/10.14232/belv.2016.1.8

Cikkre való hivatkozás / How to cite this article: Balogh, Péter (2016): Hungary in the Rural Development Cooperation Network of the European Union. Belvedere Meridionale vol. 28. no. 1. 114-134. pp

ISSN 1419-0222 (print) ISSN 2064-5929 (online, pdf)

(Creative Commons) Nevezd meg! - Így add tovább! 4.0 (CC BY-SA 4.0)

(Creative Commons) Attribution-ShareAlike 4.0 International (CC BY-SA 4.0)

www.belvedere-meridionale.hu 


\section{Introduction}

In this paper we introduce some results from our explorative empirical investigation about the implementation of the European Union rural development policy. In the focus of our research the bottom-up character of EU rural development - and especially the position of Hungary in this processes - can be found as we concentrate on the analysis of territorial cooperation projects in the planning period between 2007 and 2013. After introducing the research issue theoretically in the terms of local development, social factors and embeddeness of development - with a specific attention on rural development - the data sources and methods are described. In the process of data analysis we employ on the one hand basic techniques and measures to reveal the main characteristics of the allocation of transnational rural development cooperation projects. On the other hand we apply network analysis techniques to explore the position of Hungary in the EU-level rural development cooperation network. According to the results available at the current level of the research the distribution of both the projects and the financial resources allocated through these ones prove to be rather concentrated, and Hungary seems to have a kind of comparative advantage in the possibilities of the initiation of transnational cooperation projects.

\section{Theoretical introduction}

\section{Local development and social embeddedness}

Considering the concept of local development from the general perspective of territorial development it can be defined as a rather comprehensive activity including a certain number of social and economic actors that complement each other. This process of joint activities happens in a specific local level and as a result of these activities the best possible form of utilization of local resources can be achieved leading to the development of the area implied. The activities and actions of the local actors can be found in the focus of local development processes who take steps in favour of the development of the area, and this specific aspect of local social embeddedness (GranovetTer 2006) of development processes is rather significant (REISINGER 2010. 12.). The social background of local development highlighted above might be interpreted from a(n economic) sociological aspect building on the concept of social capital.

The important role of social capital ${ }^{1}$ - or as it is usually referred to by the literature; third sector (Birch -Whittam 2008) or civil sector (KELEMEN 2005) - in the development of societies or communities is highlighted by Putnam's well-known thesis (Putnam 2006), but for our topic it is even more important that this role is also emphasized in regional development policy. The definition of this special kind of resource shows differences according to distinct authors who underline certain aspects of the concept - for some of the definitions, interpretations and misinterpretations see SIK (2006). However it is common to all of the concepts, definitions and interpretations of social capital that it is more or less connected to civil organization (ORBÁNSZÁNTÓ 2006. 139.; FÜZÉR-GERŐ-SIK-ZONGOR 2006. 340., 343.) as amongst the mechanisms of

\footnotetext{
${ }^{1}$ The role of social capital in local development and development policy can be highlighted even more if development policy in general is interpreted as an intent to help public goods (OLSON 1997) to come into existence - or rather to prevent public bad (Hirschman 1995) - employing institutional devices (ELSTER 1995) in order to enforce certain principles. In this aspect social capital can facilitate collective action and eventually the success of development processes.
} 
social capital can be found - among others - community development based on social networks, competitiveness, collective action capacity and social cooperation (OrbÁN - SzÁNTó 2006. 142.). The most important political function of social capital can be considered to expand and to strengthen civil society. The abundant amount of social capital is the criterion of a vibrant civil society, which in turn is essential to the effective operation of a democratic political system (Orbán-SzÁntó 2006. 144.).

Putnam (2006: 208) exactly states that the communities with adequate set of social capital enjoy the benefits of higher economic growth, lower crime, extensive socialization, improved mental/medical conditions or better school performance (ORBAN - SzÁnTó 2006. 143.).

However, the sole existence of social capital is not necessarily the guarantee of competitiveness and development as it is also possible that civil society itself becomes the hotbed, glass culture of rent seeking (see JoHNSON 1999. 236-244.): certain actors of civil society over time are transformed into interest groups which may utilize community funds for their private purposes (ORBÁn-SzÁnTó 2006. 144.).

This type of resource or capital raised also the interest of decision-makers and practitioners: from the 1990s - beside the academic interest - the attention of public policy towards these resources became more intense. Social capital might be interesting in the development policy for two reasons: (1) to grasp the impact of the (existing) social capital in the system, and (2) - in the light of methodological individualism - the creation or formation of social capital is usually an unintended by-product due to the tradition, the history of coexistence, shared historical experience, religion and related social factors - and as such, the government has only a limited direct impact on social capital formation (OrbáN-SzÁntó 2006. 150.). Accordingly, various development institutions - e.g. World Bank, European Commission, even in Hungary (FüZÉRGerö-SiK-Zongor 2006. 337.) - started to build more significantly their activities aimed to foster economic growth and sustainable social development on social capital (OrBán-SzÁnTó 2006. 139.; FÜZÉR-GERŐ-SIK-ZONGOR 2006. 336., 343.). In the research field of general regional development one of the main questions are the possibilities of social capital development (BIRCH - Whiтtam 2008). As there seems to work a special kind of interaction: social capital can be accumulated and developed by the third sector, and - in turn - the latter boosts and strengthens - by activating different actors in a network structure - sustainable regional development (Birch - Whittam 2008. 438.). At the same time the civil organizations gain more and more significant economic, social and political role to the transformation processes of EU development policy - primarily in the implementation of and decisions connected to local- and regional level territorial development programs (KovácH 2000. 185.; KovácH 2010. 26.; 184.), furthermore the focus on the principles of partnership and cooperation (HORVÁTH 2003. 147-151.; BERKY-KULLMANN 2011.9-10). As in the solution of the problems emerging from the rapid globalization of the economic and environmental changes, the increasing process of individualisation, the great changes in the political sphere - the collapse of socialism, the transformation of the European community - new forms of cooperative methods became necessary. In this context of regional development the civil organizations become involved in the integration of human and economic resources of sub-national (local, regional) level and in the fostering of the responsibility-sharing processes among different levels, cooperation and networking - providing a forum for bottomup, participatory development practice (KovÁcH-KuČEROvá-MEGYESI 2005. 109-110). 


\section{Features of EU rural development policy}

In the system of the European Union rural development policy certain approaches and factors need to be taken into consideration regarding the micro-level realization or implementation of the objectives, i.e. to encourage the potential actors and stakeholders to mobilize their resources to reach the general aims through the realization of particular or individual aims. In this context projectification (KovÁCH-KuČEROVÁ 2006; KovÁcH 2007) proves to be an important factor implying that the overall process of development policy is organized through individual initiations; projects that include the individual intentions, motivations and resources of the participants. These projects in rural development policy play an important role - building on the role of communities and the principle of partnership (KovácH-KuČEROVÁ-MEGYEsi 2005) - in the commercialization of rural goods and services (KovÁCH-KRISTóF 2007). A further relevant aspect of the projectified rural development policy is its emphasis on endogenous development and the role of decentralization (Csite-Kovách 2002, DAvey 2003) and locality (BARCA 2009) in a cooperative and network-based manner. In a general perspective CHANAN (1999) describes the evolution of the participation of local actors through networks in a pyramid model (CHANAN 1999. 38.). According to this scheme the possibilities of the local participants intended to facilitate and promote the development of their area begin at a phase when individuals start to establish community groups or take part in activities of such already existing groups. After one is a member - or even initiator - of a group the next step is to become active as a member of the group through gaining an essential - first of all developmental - role in the activities of the group. In this phase work is needed to assist group formation, to develop basic organizational skills, trust and confidence, the clarification of the objectives of the group. After a group has firmly established itself through the organizing work of some relevant members and with the possible help of already established groups or umbrella organizations the next step is to find further actors and/or other group(s) that might be partner(s) in reaching objectives. In this cooperative phase strategic planning of the activities of the groups is considered, the skills of the staff and the volunteers become more important, and this step may involve the widening of social or geographical base of the people reached by the group. When this cooperation amongst groups or organizations becomes sound and effective, certain umbrella groups, forums and networks may arise. In this phase it becomes possible for the groups to provide certain services to their members, the cohesion of the community and the voluntary sector is increased and the relationships with other sectors become more frequent. Finally, this organized agglomeration of individual actors through groups enters the public sphere by representing the members and stakeholders and by articulating the objectives and strategy of the cooperation. While acting in the official scheme it proves to be significant for the representatives of the network to be able to, or to have assistance in negotiating with authorities and different power-holders. In this context the possibility appears to shape the overall development of the locality and its population, and the final aim can be reached (CHANAN 1999. 38-39).

If this evolution of participatory processes is managed successfully the involvement becomes mutually beneficiary between the different levels of development. This other pyramid model (Figure 1) highlights that after a certain level of organizational structure the networks evolved not only strengthen the groups contained but the networks support a scheme and - at the top of the structure - after a certain level the scheme itself starts to support the networks and through the networks the groups and finally at the lowest - local - level the participants, the individuals forming groups - i.e. those who were originally initiating the whole process (CHANAN 1999. 39-40.). 


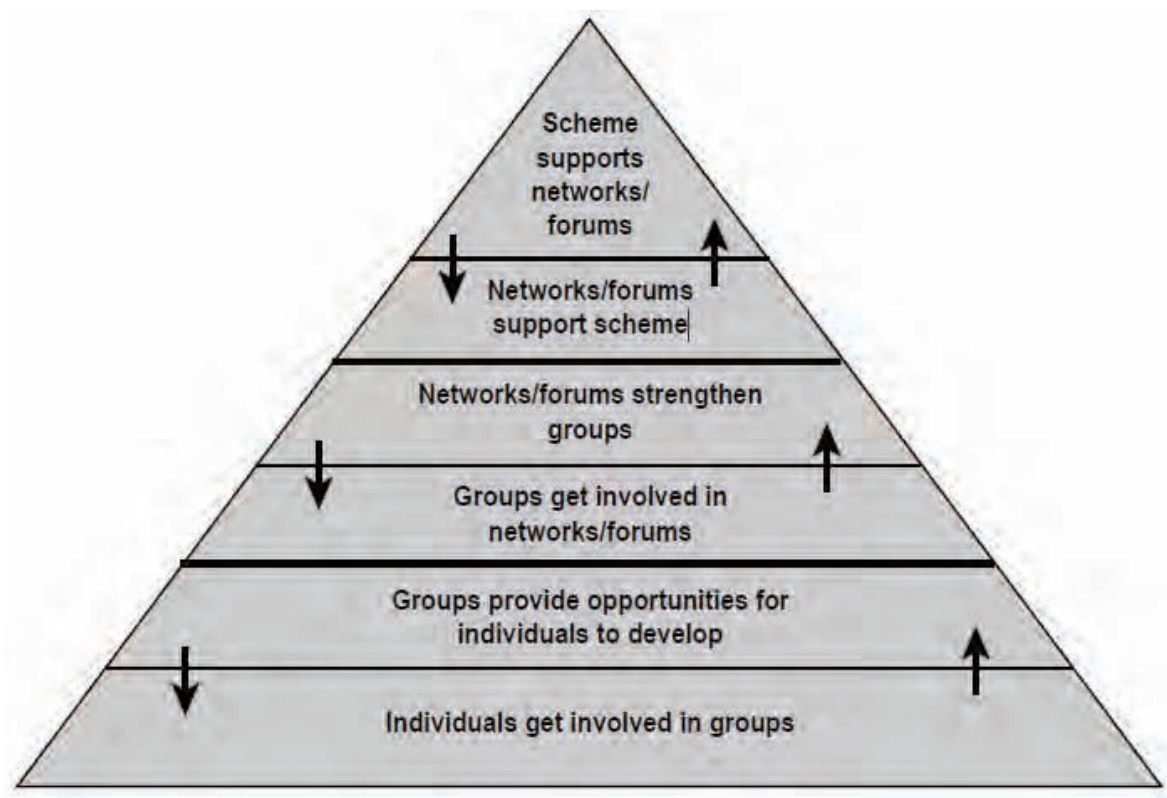

Figure 1 The involvement pyramid (source: CHANAN 1999. 40.)

In our study these participatory and involvement models can be easily applied to introduce and interpret the structure and implementation of the European Union ${ }^{2}$ rural development policy. As in this perspective the rural development policy was - at least partially - based on a rather similar structure as the aforementioned pyramid model: in each member states the rural areas were formally organized through the so-called local action groups (LAG) system. Local action groups could be formed - in this aspect - by local people and/or local groups and organizations ${ }^{3}$ engaged in local development. After these local actors - or the groups of these

${ }^{2}$ It is relevant even in Hungary demonstrated by the potential possibility - created by the Regional Development Act in 1996 - for local government to create associations (Micro-regional Development Councils) - which actually are a form of voluntary/non-governmental organizations. Furthermore all of those sub-regional level active social organizations can participate in the work of these Micro-regional Development Councils which cover at least half of the regarding population or settlements. In addition since 2004. it is regulated by governmental decree how - in an official form - civil organizations can articulate their opinions and express their interest in the process of local and regional decision-making and strategy-building. The scene of this formal representation is the civil forum, which may delegate members to the concerning development council (NaGy 2005. 15-16.; Kovách-Megresi-Nagy 2005. 78-79.).

3 This seem to be in accordance with the methodological problem of the measurement of the quantity of social capital. As in the literature there can be two different approaches distinguished (ORBÁN-SzÁNTó 2006: 145): (1.) the one based on the number of groups and group members and (2) the other one based on the social level trust and the extensiveness of civil organizations. ORBÁn A.-SzÁnTó Z. (2006. 145-147.) describe the following analytical model to measure social capital in the light of the former (1) approach:

$$
\mathrm{SC}=\sum\left(1 / \mathrm{r}_{\mathrm{n}}\right)\left(\mathrm{r}_{\mathrm{p}} \mathrm{cn}\right)_{1 \ldots \mathrm{t}}
$$

Where ' $n$ ' indicates the number of members of a certain civil organization and ' $t$ ' signifies the number of groups concerned, ' $r_{n}$ ' indicate the radius of distrust - which comes into existence in the case of groups or 
local actors - have gained the official representative role, i.e. the LAG status they could have become a possible member of a specific network of groups (European Network for Rural Development; ENRD). The motto of ENRD says 'Connecting Rural Europe' and by joining this umbrella organization the potentials of local actors (or local network of actors) highly increases. As the European Network for Rural Development helps to coordinate and facilitate the information sharing processes in order to develop rural development networks through specific cooperation projects. This was achieved by a central webpage with a list of different project proposals announced by the initiator local action groups themselves and expecting other LAG's to participate as partner in the case when they have similar objectives. The successful cooperation project proposals can realize the desired rural development objectives in a cooperative structure with financial resources from the official budget. In this manner the scheme funded by the network of the groups begins to help the organizations and the (local action) groups, and through them the actors themselves to reach their specific, locally embedded aims and the scheme as a whole starts to work as an assisting structure.

\section{Data and methods}

In order to to investigate empirically the rural development policy of the European Union at first stage we assembled a project-level database. The source of this dataset was the official list of the transnational cooperation projects of the European Network for Rural Development in the period of $2007-2013^{4}$. Based on the information included in the project list some main features of the projects were gathered through variables ${ }^{5}$ for a total number of 448 projects. So this ready-to-be analysed dataset contained all the projects officially notified by the policy-makers - until 2014.06.13. - which means that we have not applied sampling methods but investigated the whole population of the TNC projects ${ }^{6}$. At the second phase of the data management the initial project-level database was aggregated on country level - including only the European Union member states - resulting in a specific database ${ }^{7}$ containing the paired values of overall (cooperation) links between the countries through transnational cooperation projects.

Accordingly in the course of data analysis, two kinds of units can be distinguished: while exploring the main characteristics of the distribution of projects and budget the units of analysis were the individual projects. Beside that the other unit of analysis were the aggregated data on country level containing the data of (one-fold ${ }^{8}$ ) country-to-country links.

organizations that inflict negative external effects on the whole of the society, i.e. harmful and dangerous -; ' $r_{p}$ ' means the radius of trust - namely when the cooperation norms of the groups spread out of the group as positive externalities -; and ' $c$ ' is a coefficient expressing the cohesion of the organization, i.e. the collection action ability of the group members. So in this approach the rate of social capital is in inverse relationship with the negative externalities produced by the groups, but it is increased by the capacity of cooperation beyond their organizational borders and by the cohesion of the group members (OrBÁN-SzÁnTó 2006. 145-147.).

${ }_{4}^{4}$ This phase proved to be rather time-consuming as the list of the notified projects was available only in pdf format and the information about the projects had to be recoded one-by-one in an Excel spreadsheet that difficulty might be important regarding some inaccuracy in the database.

${ }^{5}$ A more detailed description of the variables is attached in the appendix.

${ }^{6}$ Therefor in the course of data analysis we do not use significance tests, the results are explored from the population.

${ }^{7}$ In the case of four projects the lead partner is not nominated in the original project list so the relevant number of the cases in this second database is 444 .

${ }^{8}$ In this stage of data analysis we recoded the information about cooperation in a dummy variable format. 
The methods of data analysis included basic descriptive statistics about the distribution of the projects amongst EU member states supplemented with concentration measures (Hoover index, Robin Hood index ${ }^{9}$ ) to quantify the inequalities and correlation coefficients to express the relations between the variables. Beside that we apply basic network analysis techniques and network measures (Freeman's degree centrality) to illustrate and describe the transnational cooperation network amongst countries in the European Union.

\section{Results of data analysis}

\section{Allocation of TNC projects}

Regarding the distribution of the rural development TNC projects remarkable differences can be observed: some of the member states (Croatia, Cyprus, Malta, Portugal and Romania) have not joined - successfully ${ }^{10}$ - the process of building EU-level rural development cooperation network as a lead partner. However the rest of the EU 28 countries also seem to vary considering

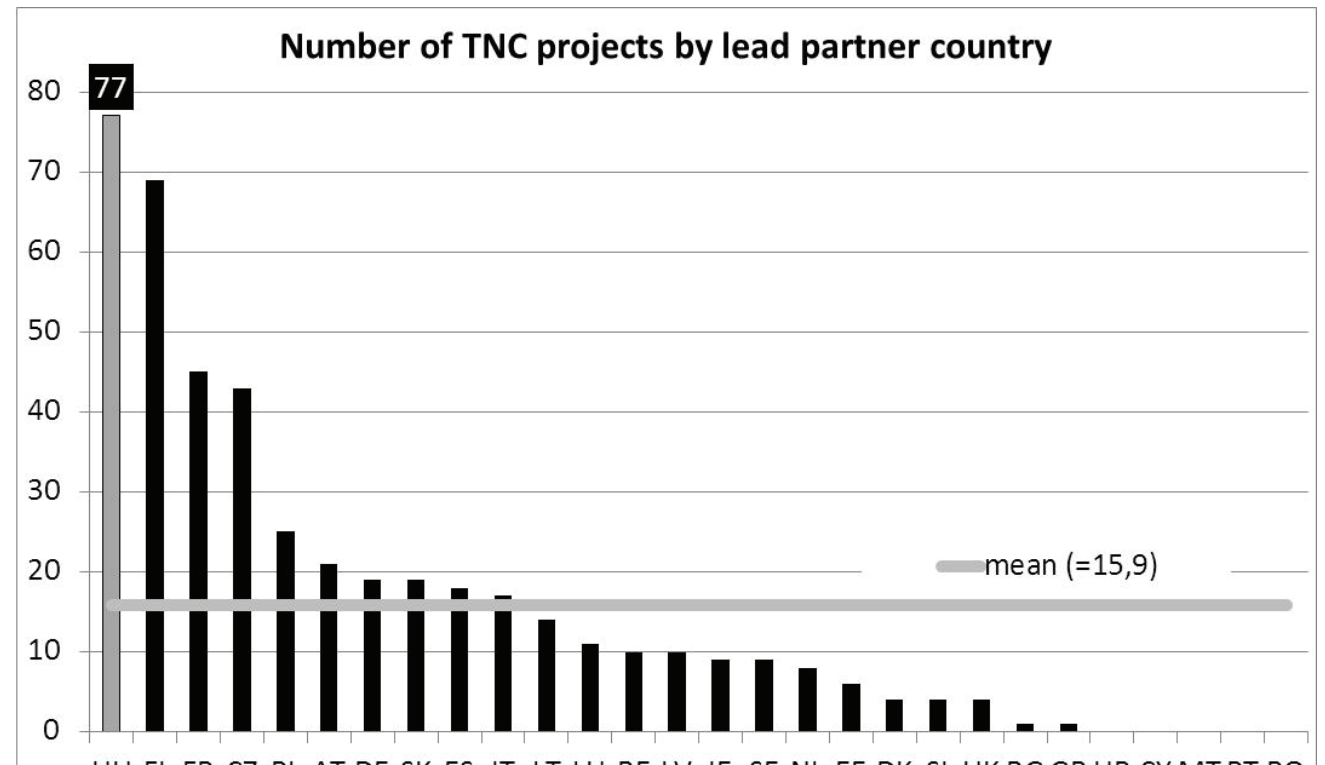

HU FI FR CZ PL AT DE SK ES IT LT LU BE LV IE SE NL EE DK SI UK BG GR HR CY MTPT RO

FIGURE $2 *$ Number of TNC projects by lead partner country

That is in a case of a certain transnational cooperation project we only encoded if a certain country - or more accurately a local action group from a certain country - is part of the project as a lead partner or as a project partner, and it was not coded if more LAG's from the same country were part of the cooperation. Namely the data really reflects the country-level cooperation and not the LAG-level links.

9 Hoover index measures - by taking into account the distribution of two variables compared to one another - the rate of the quantity of one variable needed to be reallocated in order to fit the distribution of the other variable. Robin Hood index is a special form of Hoover index in the cases when the comparison is between the distribution of the population and the distribution of income.

10 As it might be that these countries also had project proposals and partner requests for certain activities however the notified database does not include any approved TNC projects from these counties. 
their activity level to initiate cooperation as the number of TNC projects notified as lead partner is below the overall mean value $(15,9)$ in the case of further thirteen member states (see Figure 2). That is the number of TNC project initiations in most of the EU member states is smaller than the overall average. Another group of the countries is the ones with a relatively higher level of activity (Poland, Austria, Germany, Slovakia, Spain, Italy); characterized by a number of EU rural development cooperation projects above the overall average. However there can be distinguished a kind of cluster of top countries (Hungary, Finland, France, Czech Republic) which prove to have the most initiative with an outstanding number of TNC projects - including Hungary with a maximum of 77 projects, $17,3 \%$ of all the projects - organizing them as lead partner. Thus the general pattern of the distribution of EU cooperation projects prove to be a rather unequal one with a high level of concentration: more than the half of the projects $(52,7 \%)$ is initiated by only four EU member countries - only two of them are a kind of 'longer-term members' of the community (France as a founder and Finland since 1995) while the other ones are relatively 'newcomers'. The disproportionate pattern can also be demonstrated by the fact that these four top EU member states possessing more than fifty percentage of the projects incorporate - on country level - only less than one fifth $(19,8 \%)$ of the local action groups (LAGs; total number $=$ 2451 in this planning period of European Union rural development policy) authorized to launch, organize and manage rural development projects in the European Union.

In this context the distribution of TNC projects amongst countries seems to be only slightly connected to the distribution of local action groups organized in the member states. There can be measured a generally positive relation between the share of cooperation projects and LAGs on country level (see Figure 3): the higher the number of local action groups is, the more projects can be found in the countries as an overall trend $(\mathrm{R}=0,30)$, however several exceptions can be found. In the EU member states where the highest number of local action groups were organized (Poland, Spain, Germany) a relatively smaller percentage of projects were initiated. In the cases of for example France, Austria, Latvia, Ireland etc. approximately corresponding values can be measured, however regarding Hungary, Finland, the Czech Republic and Slovakia the share of TNC projects is much higher compared to the percentage of LAGs - that is these member states seem to be 'over-represented' in transnational rural development cooperation projects in relation to their relative importance or presence in the overall rural development space of the European Union.

Figure 3 Share of projects by the Nof LAGs in the country

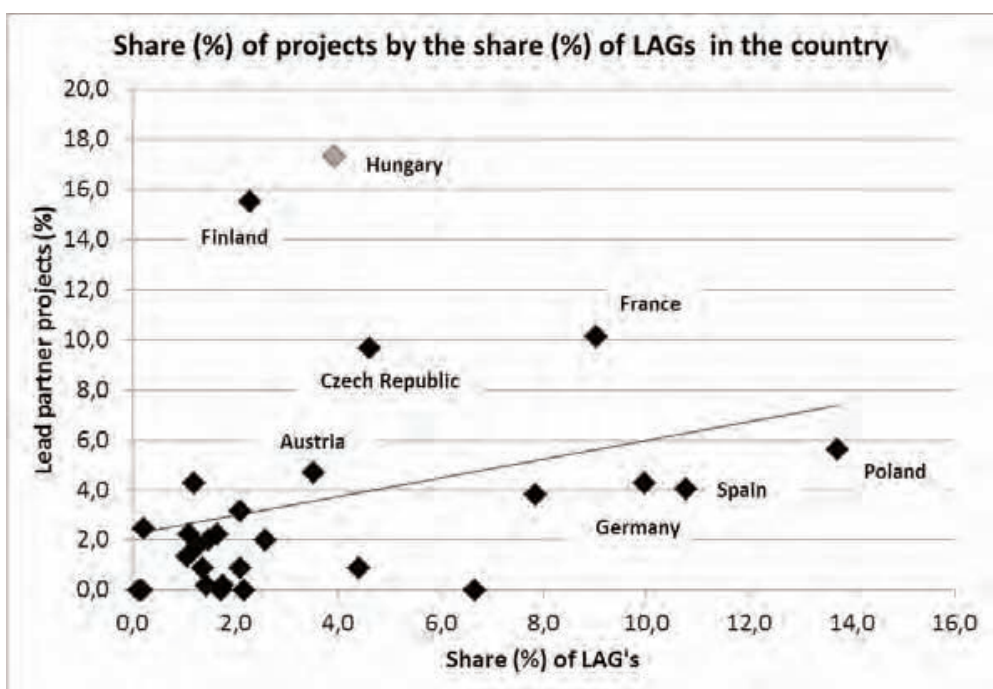


Through the value of Hoover Index we quantify the degree of concentration and demonstrate (see Figure 4) the divergence between the distribution of the projects and the local action groups amongst the EU countries measuring a value of $43,7 \%$ which implies that more than two-fifth of the projects should be reallocated amongst the countries in order to fit the distribution of LAGs amongst the member states.

FIGURE 4 Share of TNC projects by share of LAGs

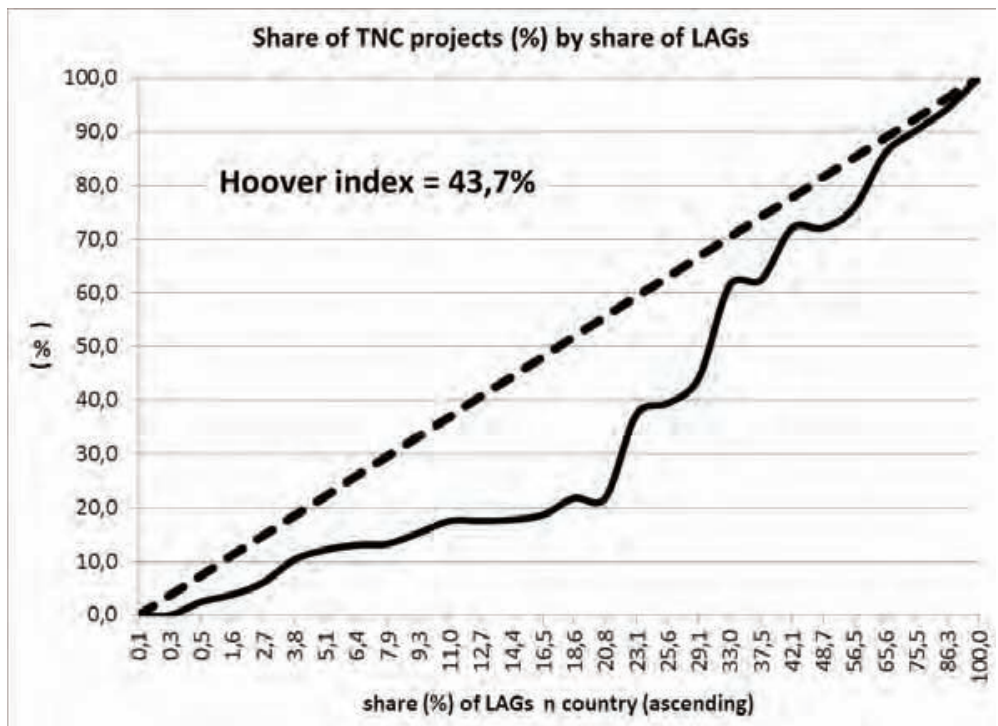

In the planning period between $2007^{11}$ and 2013 a total budget of 68535 086,1 Euro were allocated amongst the EU member states to fund transnational cooperation. The temporal dynamics of the fund allocation process (see Figure 5) reflects a kind of natural saturation through the years of the planning period; on the contrary in Hungary a kind of discontinued pattern evolves. In this case a total sum of 3596 355,5 Euro were acquired as budget - only 5,2\% of all the budget - for TNC projects and the process of fund absorptions proves to be rather uneven as in 2008, 2009 and 2012 no funds were procured in TNC projects with Hungary as a lead partner.

The relatively high number and the relatively low overall budget of the rural development cooperation projects of Hungary obviously explain that amongst the EU countries Hungary is the last one with the lowest mean value - considering the countries which have TNC projects as lead partner - in the sequence of budget per project. The group of countries characterised by the lowest values (Ireland, Latvia, Slovenia, Greece and Hungary) is followed by another cluster (including Belgium, Sweden, Estonia, Netherlands, Czech Republic, Lithuania, Slovakia and Poland) with also relatively unfavourable positions (see Figure 6).; i.e. budget per project values lower than the overall mean value (=158 313,3 Euro). Finland is also slightly above the mean, but Germany, France and Bulgaria, and even Luxembourg and the United Kingdom are the countries that have a mean value of budget per project exceeding the overall average. The group of the countries

${ }^{11}$ The fund allocation process - i.e. the actual payments to finance actual transnational cooperation projects - begins in 2008 presumably due to that the first year of the planning period was utilized as a preparation including project generation, finding partners for project plans, projects submission, assessment and decision about granting. 
at the top of the sequence is formed by Italy, Denmark, Spain and Austria - none of them is amongst the highest initiators.

Investigating the distribution of the total financial resources allocated for the EU member states to promote transnational cooperation an essentially similar pattern can be seen - at least concerning the countries characterised by the highest values (see Figure 7). Italy, Austria and Spain are again amongst the top countries - accompanied by Finland being the first one - accumulating the highest percentages of the TNC budget. Compared to the budget mean values per project Hungary in this aspect gains a relatively higher position - with the Czech Republic and Germany - as these countries acquire only a bit lower portion of the overall budget than the overall mean $(=6,7 \%)$. All the other member states are more notably (Luxembourg, France, Poland and Denmark) or rather significantly (Slovakia, Lithuania, Belgium, Sweden,

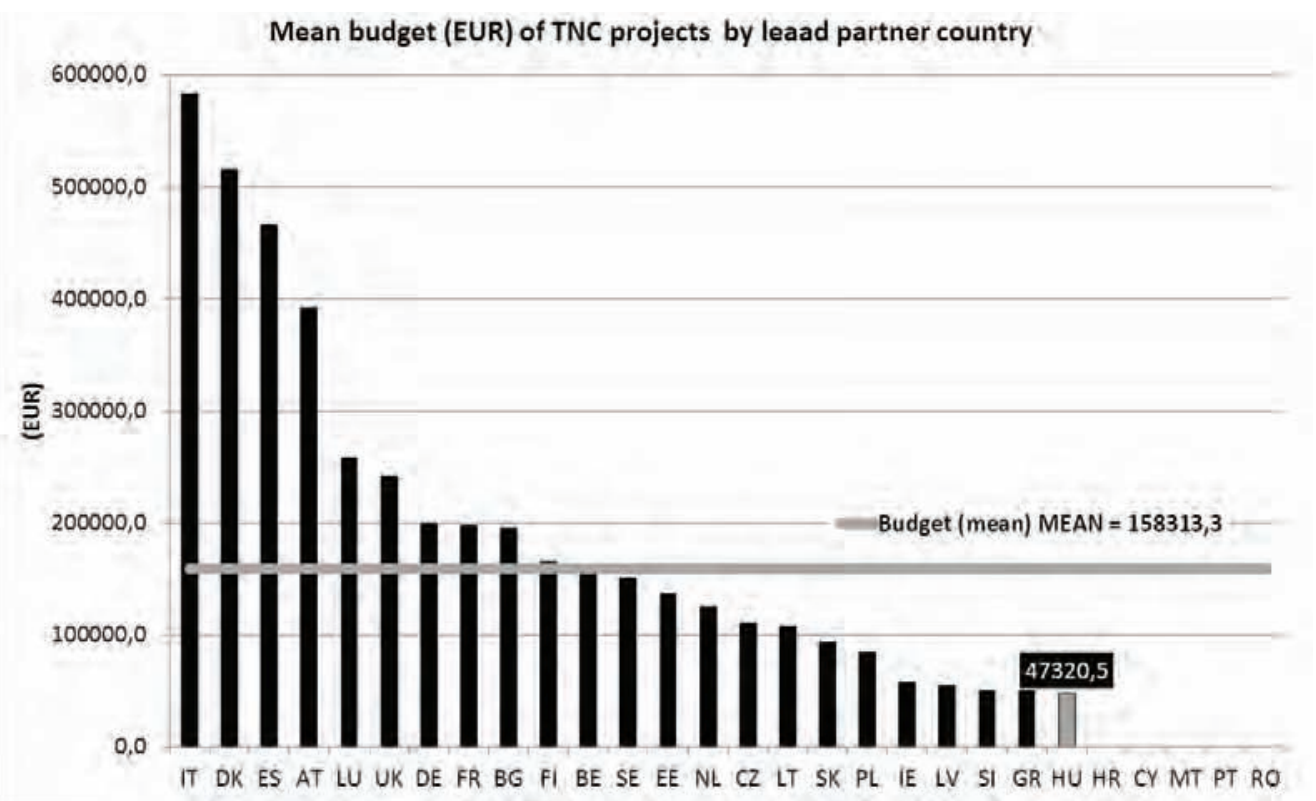




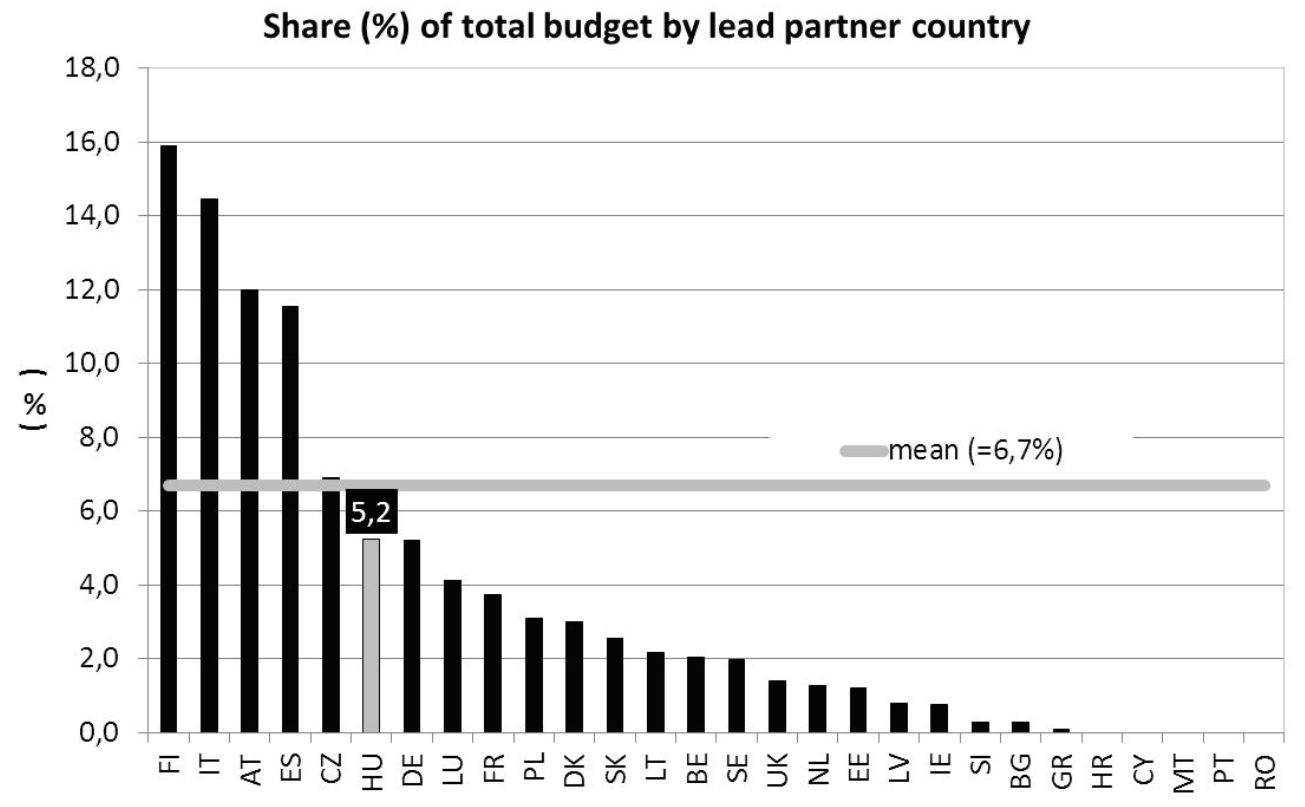

FIGURE 7 Share of total budget by lead partner country

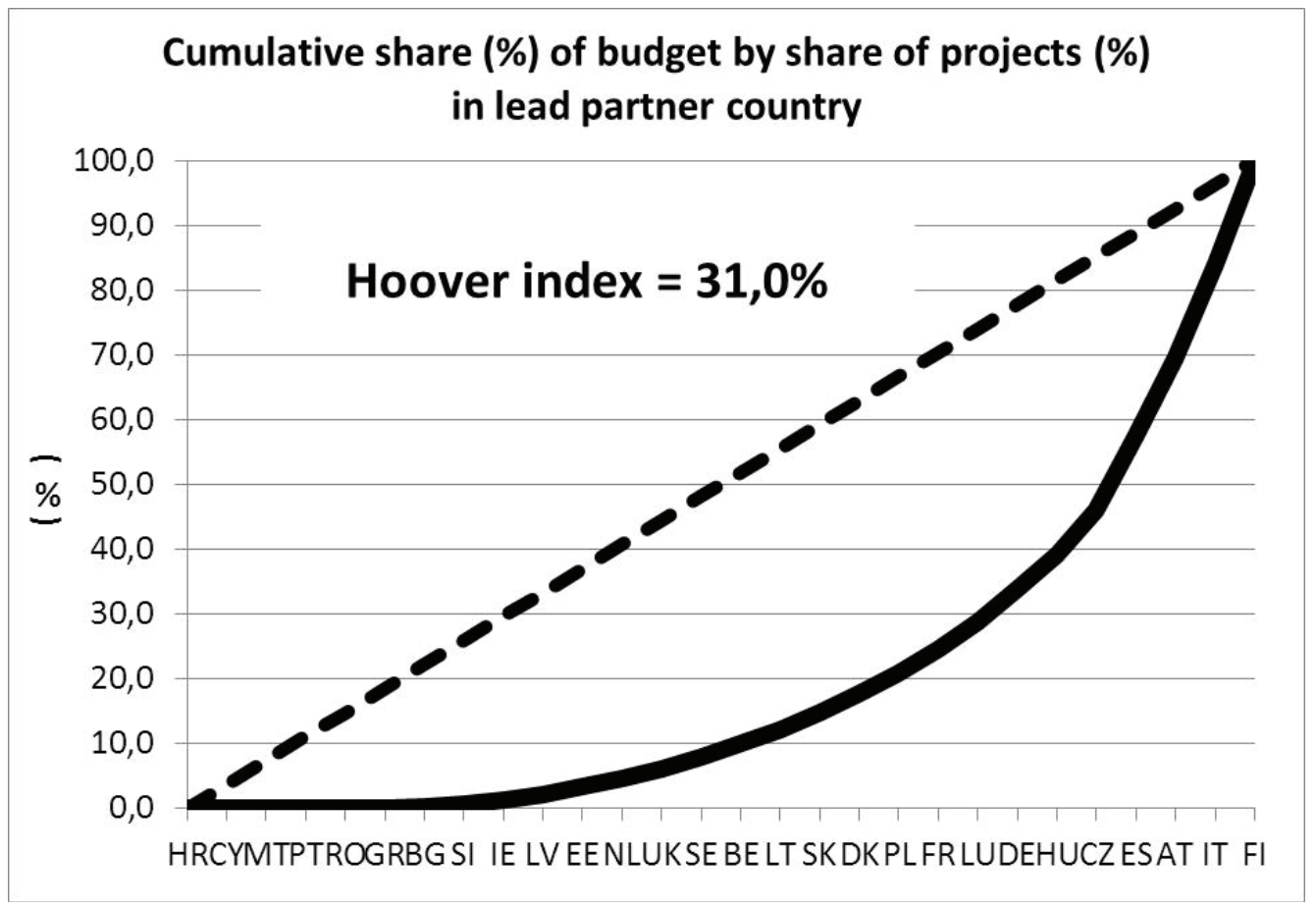

FIGURE 8 Lorenz curve of TNC projects and TNC budget 
United Kingdom, Netherlands, Estonia, Latvia, Ireland, Slovenia, Bulgaria, Greece) below the mean value - not to mention the countries that do not have projects as lead partner (Croatia, Cyprus, Malta, Portugal and Romania). Accordingly the allocation of budget amongst countries proves to be remarkably unequal: more than the half (54\%) of the budget expended is acquired by four lead partner countries. Furthermore it can also be ascertained that this high rate of the total financial resources covers only one-fourth $(24,4 \%)$ of all the local action groups concerned (on country level), and less than one-third $(28,2 \%)$ of the TNC projects.

The overall measure of inequality (see Figure 8 ) also highlights the lack of accordance between the country-level distribution of projects and financial costs: the Hoover index between the relative frequency of projects and share of total budget $(\mathrm{HI}=31 \%)$ indicates that almost one-third of the accounts should be reallocated in order to fit the - country-level - pattern of the allocation of transnational cooperation projects.

\section{Rural development cooperation network}

The highest number of partner countries in the transnational projects can be measured in the case of Germany ${ }^{12}$ : in the 19 TNC projects initiated by - local action groups in - the country an overall number of $64 \mathrm{LAG}$ 's in other countries took part in as partners leading to the average number of 3,4 links per projects (see Figure 9). Denmark, the United Kingdom and Spain forms the group of countries with a remarkably higher value, furthermore Slovenia and Italy are still amongst the countries over the mean value $(=1,9$ links). Relatively more lower values - compared to the mean - can be measured in the case of the Czech Republic, Sweden and Hungary also can be found in this cluster with average value of 1,4 links per projects. At the end of the se-

FIGURE 9 Number of partner countries reached per projects

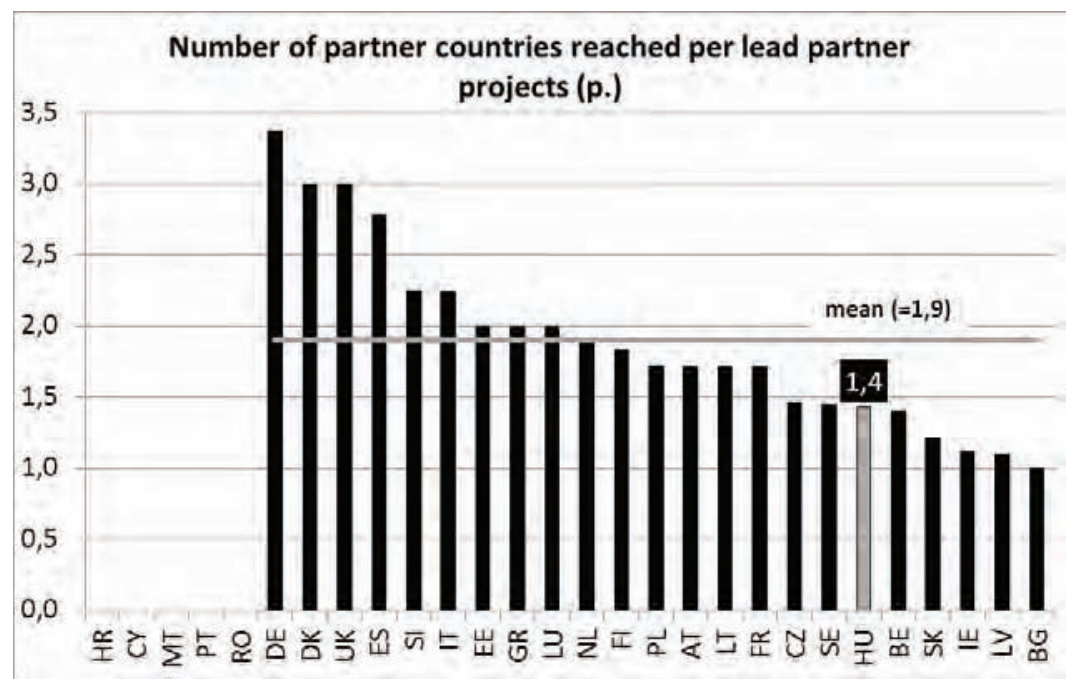

12 Obviously those EU member states that do not have transnational cooperation project initiated - Croatia, Cyprus, Malta, Portugal and Romania - are excluded from this comparison. 


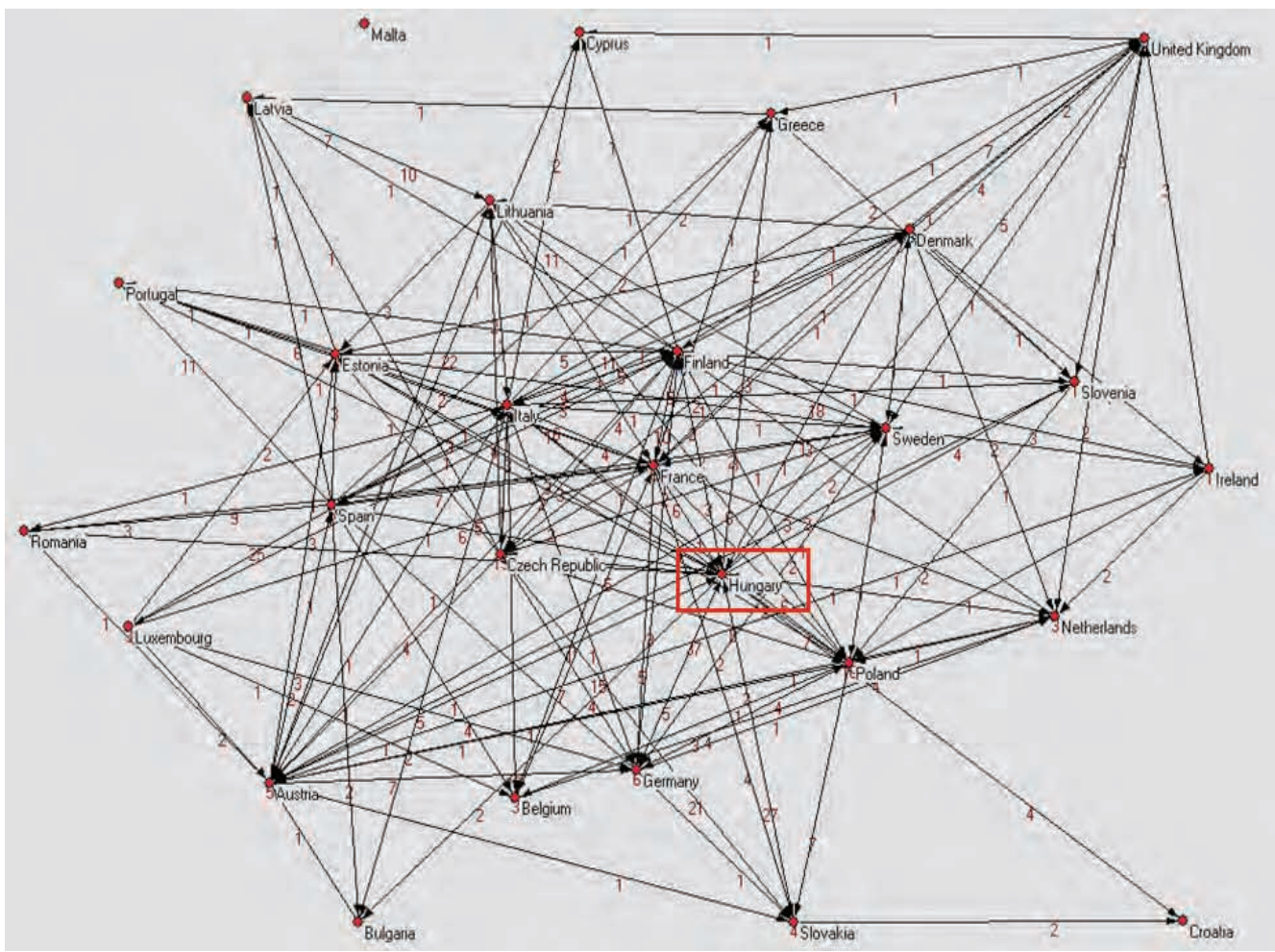

GRAPH 1 Cooperation network between countries of EU TNC projects

quence Ireland, Latvia and Bulgaria can be seen characterised by the lowest values $(\sim 1,1)$ of links per TNC projects.

The graph of the cooperation network between the countries (see Graph 1) shows a slightly different pattern compared to the above relative distribution of links per initiated TNC projects as - aside from one country; Malta that do not have any connections - all the member states of the European Union are embedded more or less in the cooperation network: at least as partner country in transnational cooperation project initiated by a different country. However there seem to be a kind of hierarchy (network centralization $=11,15 \%$ ) amongst the countries in the system as some of them can be found in the inner part of the network while others at more further positions. It is also noteworthy that Hungary seems to be a rather densely embedded country in this network. Moreover it also can be said that if we consider this system as a symmetric one Hungary has the highest value (141) of links followed by Finland (107 links) and France (87 links).

Even that we distinguish between the relations amongst the countries as links initiated by the country ('out-degree') and links initiated by another country towards a certain country ('in-degree') Hungary still proves to have a main position (see Figure 10). As in this asymmetric approach of the network Hungary seems to have the highest value of out-degree amongst the EU member states in the rural development cooperation network. In the case of the measure of in-degree Slovakia has the highest value with a total number of 61 links but again Hungary has a central position with a relatively high value (53 links) thus being the second most popular partner in the cooperation network. 


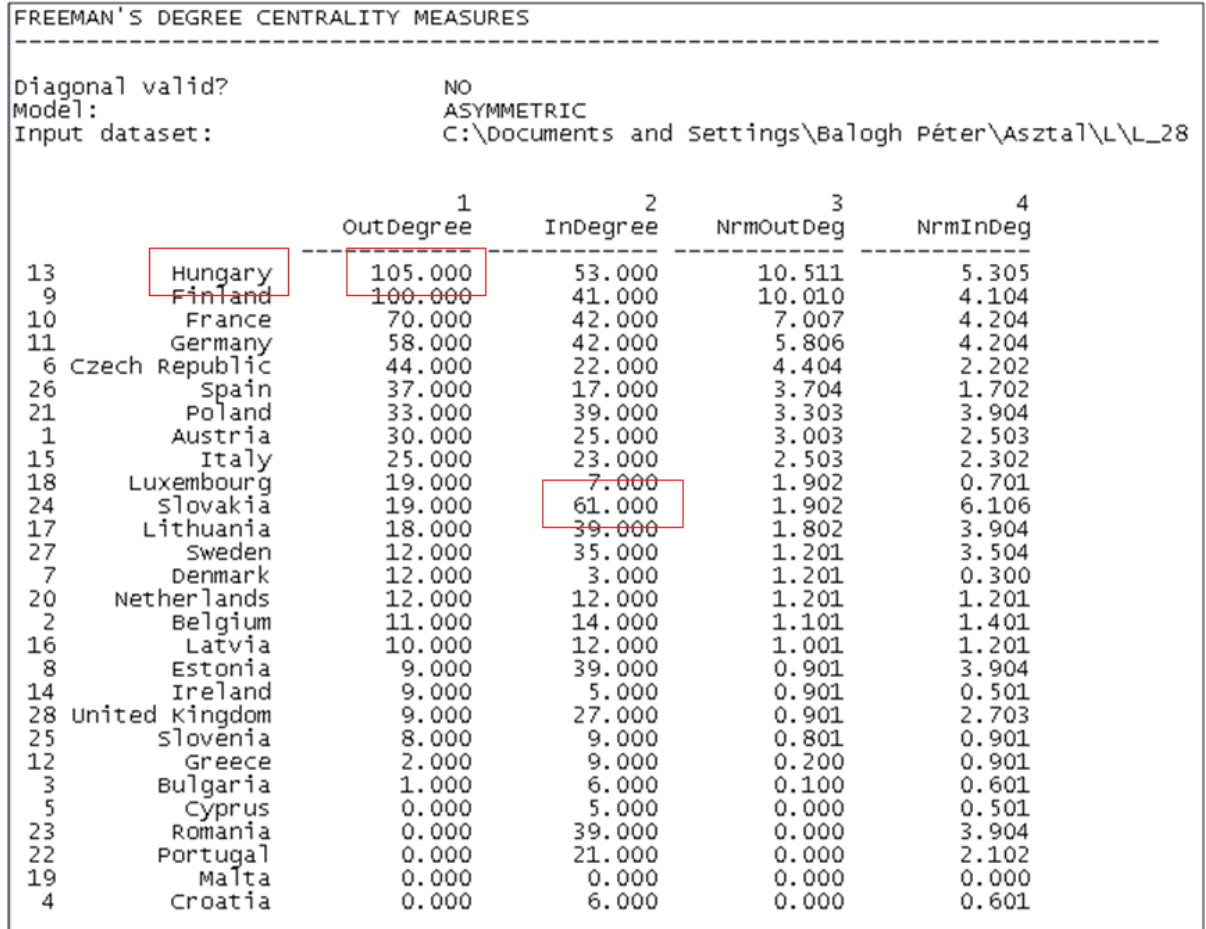

FIGURE $10 *$ Asymmetrical measures of the overall network

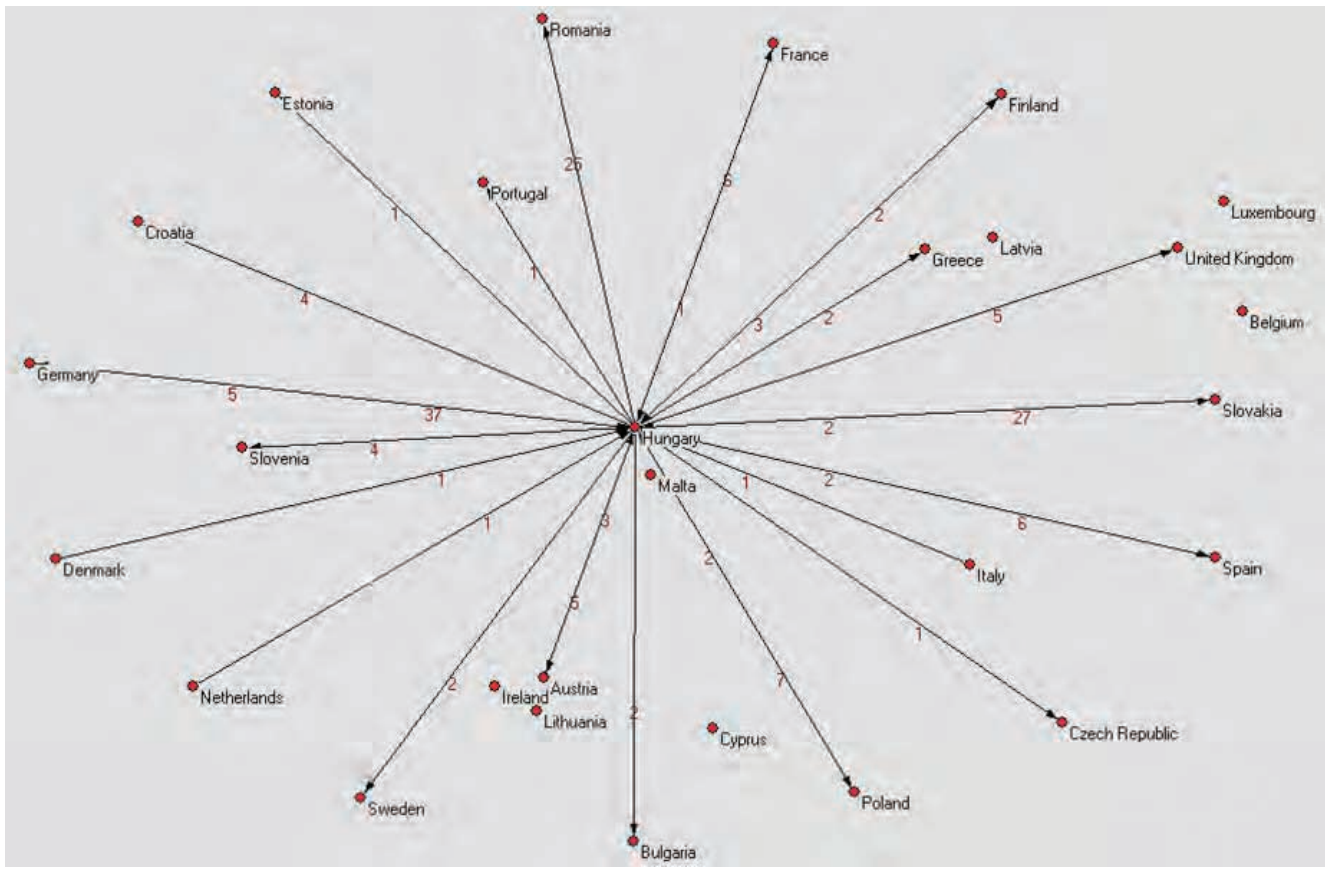

GRAPH 2 Cooperation network of Hungary in TNC projects 
Limiting this overview only to the sub-network created by the connections linked to Hungary further remarkable outcomes reveal. This part of the overall network is obviously centralized (network centralization $=14,11 \%$ ) by Hungary (see Graph 2 ) but it can also be ascertained that the composition of the links and countries is indicative in a certain sense.

In the case of the countries connected by Hungary a relatively high rate of the links point towards direct neighbour countries, namely 65 links; $61,9 \%$ of total out-degree is covered by 'cross-border' countries. The similarly measure - that is the neighbour countries choosing Hungary as a partner in transnational cooperation project - in the case of in-degree is $9,4 \%$ (see Figure 11). The tendencies explored might be interpreted as the main position of Hungary in the rural development cooperation network can be explained primarily by a strong localregional embeddedness and it cannot be excluded that certain (former, even historical) sources as a form of social capital have an important role - in accordance with the literature resources that argue that the creation or formation of social capital is usually an unintended by-product due to the tradition, the history of coexistence, shared historical experience, religion and related social factors (ORBÁN - SzÁnTó 2006. 150.). Considering for example that the major part of the connections initiated by Hungary point towards neighbour countries with potential Hungarianlanguage local action groups or members of LAG's but at this stage of the research it can only be a presupposition and that might be a further objective to verify by an analysis on lower - local action group - level.

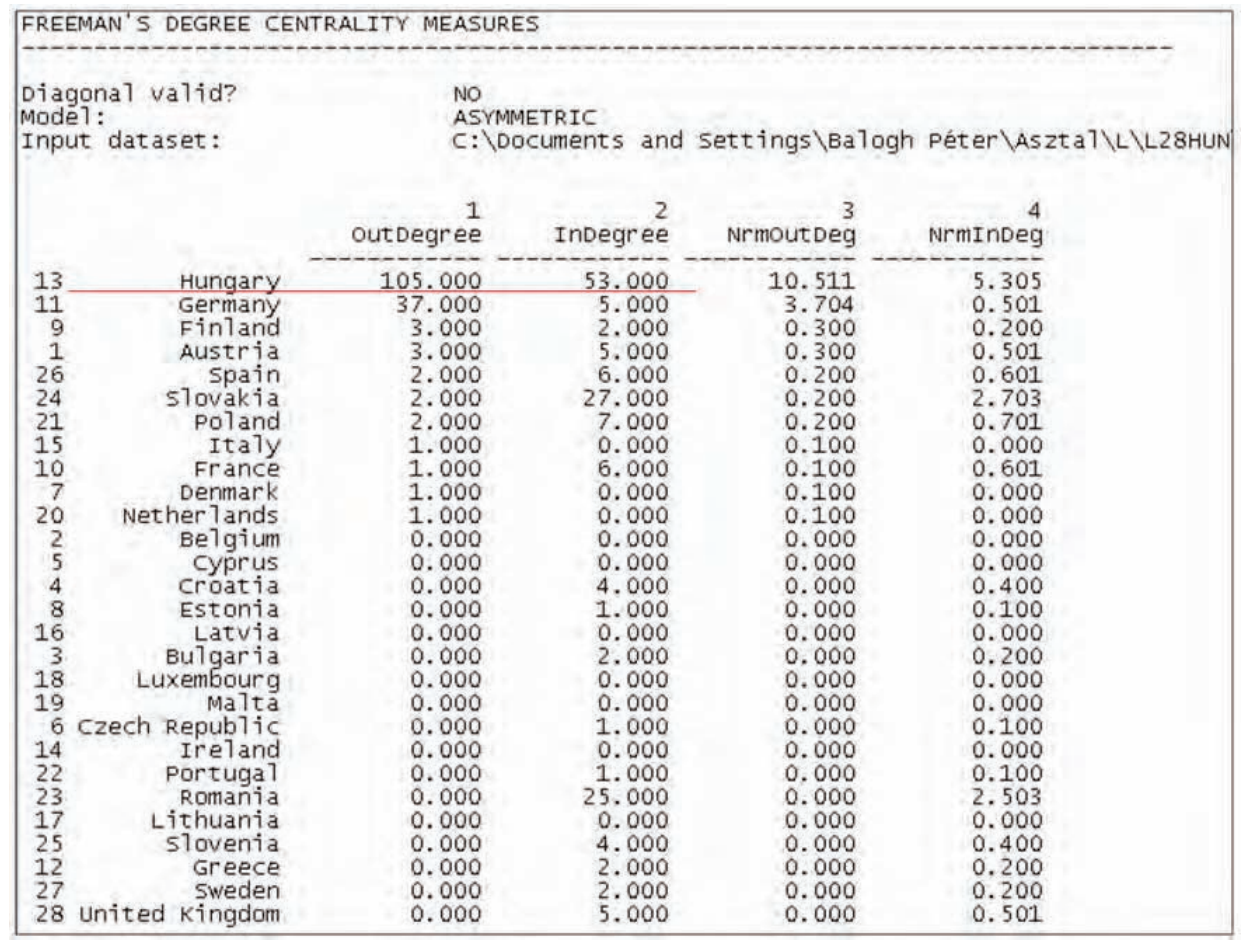




\section{Concluding remarks and further research perspectives}

Considering the results of the analysis at the current explorative stage it can be stated that on country level (1) great differences can be measured in the distribution of lead partner projects between the European Union member states; $52,7 \%$ of the projects can be found in 4 countries and (2) this rather concentrated allocation pattern is not strongly affected $(\mathrm{R}=0,30)$ by the potential possibilities of project generation; i.e. the distribution of local action groups in the countries (Hoover index $=43,7 \%$ ). In the case of funds allocation similar tendencies revealed: also (3) great differences and wide range of mean budget values between the countries with a (4) remarkable centralization of funds (54\% allocated to 4 countries) and unequal distribution compared to project distribution (Robin Hood index: 31\%).

Beside the uneven allocation of projects and funds the country-level cooperation network also proves to be (5) fragmented characterised by wide range of average number of country-tocountry cooperation links. According to the pattern of country-to-country relations (6) Hungary seems to have a central position and role in the TNC network being the most active lead partner country (with 141 initiated links) and the second most desirable partner (53 links). The latter result might be based on (7) a kind of positional advantage of Hungary as a remarkable share $(61,9 \%)$ of the links initiated is directed toward neighbour countries.

The possible further perspectives of the research may include on the one hand (1) a wider comparison of project generation processes of the countries. It might also be interesting and fruitful to explore the main demographical, sociological and economic factors affecting the differences of the distribution of rural development cooperation projects amongst EU member states, not to mention the opportunity to build an explanatory model about the success of rural development fund absorption capacities. On the other hand it seems also promising to (2) execute a more detailed analysis of the cooperation network on a less aggregated territorial level. As in this first-stage explorative analysis the cooperation links were calculated between the EU member states, but the original initiators of the transnational cooperation projects according to the concerning policy are the local action groups. This approach of further research would demand - the rather time-consuming work of - (re)coding of the initial project-level data available in pdf format not on country-, but on LAG-level through identifying the nominated local action groups by the cooperation projects in the official LAG database but it might be rewarding in the sense that some of the outcomes revealed in this report could be more accurately verified. A possible further research perspective might be to (3) perform additional qualitative investigations: personal interviews with and focus group research among local action group members and/or leaders could be useful to explore the local factors and mechanisms behind rural development cooperation project generation processes.

\section{REFERENCES}

Barca, Fabrizio (2009): An Agenda for a Reformed Cohesion Policy. A place-based approach to meeting European Union challenges and expectations. Independent Report. Source: http://www.europarl. europa.eu/meetdocs/2009_2014/documents/regi/dv/barca_report_/barca_report_en.pdf (2015. 12. 9.)

Berky, TAmÁs - Kullmann, ÁdÁm (2011): Institutional Aspects of the Deveoplment of Peripherial Microregions. What Future for Cohesion Policy? An Academic and Policy Debate. Regional Studies 
Association Conference 2011. (papers) Source: http://citeseerx.ist.psu.edu/viewdoc/downloa $\mathrm{d}$ ?doi=10.1.1.226.2882\&rep=rep1\&type $=$ pdf (2015. 12. 9.)

Birch, Kean - Whittam, Geoff (2008): The Third Sector and the Regional Development of Social Capital. Regional Studies vol. 42. no. 3. 437-450.

Chanan, Gabriel (1999): Local Community Involvement. A Handbook for Good Practice. European Foundation for the Improvement of Living and Working Conditions. Source: http://www.eurofound. europa.eu/publications/report/1999/other/local-community-involvement-a-handbook-forgood-practice (2015. 12. 9.)

Csite, ANDRÁs - KovÁch, ImRe (2002): Vidéki történet. In Kovách Imre (szerk.): Hatalom és társadalmi változás. A posztszocializmus vége. Szociológiai tanulmányok. Budapest, Napvilág Kiadó. 219-308.

Davey, Kenneth (2003): Decentralization and Regional Development: The Rationale. In Davey, Kenneth (ed): Investing in Regional Development: Policies and Practices in EU Candidate Countries. Budapest, Local Government and Public Service Reform Inititaive. Open Society Institute. 3-12.

Elster, Jon (1997): A társadalom fogaskerekei. Budapest, Osiris Kiadó

FÜZÉR KATALIN - GERŐ MÁRTON - SiK ENDRE - ZongOR GÁBOR (2006): Társadalmi tőke és fejlesztés. In Kolosi Tamás - Tóth István György - Vukovich György (szerk.): Társadalmi riport 2006. Budapest, TÁRKI. 335-350.

GranovetTeR, M. (2006): A gazdasági intézmények társadalmi megformálása: a beágyazottság problémája. In Lengyel György - SzÁntó ZoltÁn (szerk.): Gazdaságszociológia. Budapest, Aula Kiadó. 32-47.

Hirschman, Albert O. (1995): Kivonulás, tiltakozás, hüség. Hogyan reagálnak vállalatok, szervezetek és államok hanyatlására az érintettek? Budapest, Osiris Kiadó.

HoRváth, Gyula (2003): Regionális támogatások az Európai Unióban. Budapest, Osiris Kiadó.

JoHnson, DAvid B. (1999): Közösségi döntések elmélete. Bevezetés az új politikai gazdaságtanba. Budapest: Osiris Kiadó. 236-244.

KeLemen, EszTer (2005): A civil szektor Magyarországon. In Kovách Imre (szerk.): A civil szervezetekés a területfejlesztési politika. Budapest, MTA PTI. Mühelytanulmányok, Digitális Archívum, 4-8. Source: http://www.mtapti.hu/pdf/mtcivil.pdf (2012. 03. 22.)

Kovách, Imre (2000): LEADER, a New Social Order, and the Central- and East-European Countries. Sociologia Ruralis vol. 40. no. 2. 181-189.

Kovách, ImRE (2007): A fejlesztéspolitika projektesítése és a projekt osztály. Hozzászólás a projektesítés következményei vitához. Szociológiai Szemle vol. 17. no. 3-4. 214-222.

KovÁch, ImRe (2010): A jelenkori magyar vidéki társadalom szerkezeti és hatalmi változásai. MTA doktori értekezés. Budapest, MTA PTI. Source: http://real-d.mtak.hu/296/4/kovachimre_5_ Mu.pdf (2012. 01. 27.)

KovÁCH, IMRE - KRISTÓF, LUCA (2007): Közvetítő szereplők a vidéki javak és szolgáltatások piacán. In Kovách Imre (szerk.): Vidékiek és városiak. A tudás-és imázshasználat hatásai a vidéki Magyarországon. Budapest, L'Harmattan - MTA PTI. 105-119.

KovÁch, ImRe - KučERová, Eva (2006): The project class in Central Europe: The Czech and Hungarian Cases. Sociologia Ruralis vol. 46. no. 1. 3-21.

KovÁch, IMre - KuČERovÁ, EvA - MegYesi, BoldizsÁr (2005): Civil szervezetek az európai területfejlesztésben. Európai tendenciák, példák. In Kovách Imre (szerk.): A civil szervezetekés a területfejlesztési politika. Budapest, MTA PTI, Mühelytanulmányok, digitális archívum, 109-135. Source: http:// www.mtapti.hu/pdf/mtcivil.pdf (2012. 03. 22.)

Kovách, ImRe - Megyesi, Boldizsár - Nagy, LuCA (2005): Értékelés és összehasonlítás. In Kovách Imre (szerk.): A civil szervezetek és a területfejlesztési politika. Budapest, MTA PTI, Mühelytanulmányok, Digitális Archívum, 78-83. Source: http://www.mtapti.hu/pdf/mtcivil.pdf (2012. 03. 22.)

NAGY ILDIKó (2005): A területfejlesztésben müködő civil szervezetek jogi és működési keretei. In Kovách Imre (szerk.): A civil szervezetekés a területfejlesztési politika. Budapest, MTA PTI. Mühelytanulmányok, Digitális Archívum, 9-16. Source: http://www.mtapti.hu/pdf/mtcivil.pdf(2012. 03.22.)

Olson, Mancur (1997): A kollektív cselekvés logikája. Közjavakés csoportelmélet. Budapest: Osiris Kiadó 
Orbán Annamária-Szántó Zoltán (2006): A társadalmi tőke koncepciója. In Szántó Zoltán: Analitikus szemléletmódok a modern társadalomtudományban. Tanulmányok a gazdaságszociológia és a politikai gazdaságtan néhány kortárs elméleti irányzatáról. Budapest: Helikon Kiadó, 137-155. Putnam, Robert D. (2006): Egyedül tekézni: Amerika csökkenő társadalmi tökéje. In Lengyel György Szántó Zoltán (szerk.): Gazdaságszociológia. Szöveggyüjtemény. Budapest, Aula Kiadó. 207-219. REISINGER, AdRIENN (2010): Társadalmi részvétel a helyi fejlesztéspolitikában - különös tekintettel a civil/nonprofit szervezetek szerepére. Doktori értekezés. Györ, Széchenyi István Egyetem. Source: http://rgdi.sze.hu/files/Ertekezesek,\%20tezisek/Dolgozat_Reisinger\%20Adrienn_vedes.pdf (2015. 12. 9.)

SIK, Endre (2006): Tőke-e a kapcsolati tőke, s ha igen, mennyiben nem? Szociológiai Szemle 16. évf. 2. sz. 72-95.

\section{APPENDIX}

A1: Description of the variables

\begin{tabular}{|c|c|c|}
\hline Variable & Source & Level of aggregation \\
\hline Number (share) of TNC projects & $\begin{array}{c}\text { official data from the European } \\
\text { Network for Rural Development } \\
\text { webpage (archived TNC projects } \\
\text { database) }\end{array}$ & $\begin{array}{c}\text { country-level } \\
\text { (EU member states) }\end{array}$ \\
\hline $\begin{array}{c}\text { Number (share) of local action } \\
\text { groups }\end{array}$ & $\begin{array}{c}\text { interactive database of the European } \\
\text { Network for Rural Development } \\
\text { webpage }\end{array}$ & $\begin{array}{c}\text { country-level } \\
\text { (EU MS's) }\end{array}$ \\
\hline $\begin{array}{c}\text { Budget (share) of TNC projects } \\
\text { official data from the European } \\
\text { Network for Rural Development } \\
\text { webpage (archived TNC projects } \\
\text { database) }\end{array}$ & $\begin{array}{c}\text { country-level } \\
\text { (EU MS's) }\end{array}$ \\
\hline $\begin{array}{c}\text { Cooperation (partner relations) } \\
\text { between countries in TNC } \\
\text { projects }\end{array}$ & $\begin{array}{c}\text { official data from the European } \\
\text { Network for Rural Development } \\
\text { webpage (archived TNC projects } \\
\text { database) }\end{array}$ & project level \\
\hline $\begin{array}{c}\text { Number of partner relations } \\
\text { between countries }\end{array}$ & owngregation & $\begin{array}{c}\text { country-level } \\
\text { (EU MS's) }\end{array}$ \\
\hline
\end{tabular}

